Hammer J, Eber E (eds): Paediatric Pulmonary Function Testing.

Prog Respir Res. Basel, Karger, 2005, vol 33, pp 181-189

Measurement of Exhaled Markers

\title{
Measurement of Nasal Nitric Oxide
}

\author{
Regula Corbelli Jürg Hammer \\ Division of Intensive Care and Pulmonology, University Children's Hospital Basel, \\ Basel, Switzerland
}

\begin{abstract}
The major part of nitric oxide (NO) in exhaled air originates from the nasal airways, with only minor contribution from the lower airways and the oral cavity. The physiological role of the very high local NO concentration in the paranasal sinuses is still unclear. The most widely used and best-standardized method to sample nasal $\mathrm{NO}$ in isolation from the lower respiratory tract is aspiration at a fixed flow through the nasal passages in series. Important technical considerations include the choice of the correct transnasal flow and the ability of children to perform a breath-holding manoeuvre. The effects of age and height on nasal NO values have yet to be defined in a larger population of healthy children using the recommended aspiration technique. Presently, there is no validated technique available to measure nasal $\mathrm{NO}$ in infants and small children. The measurement of nasal NO concentrations has evoked interest in its potential to serve as a non-invasive and simple diagnostic tool for upper and lower respiratory tract disorders. Measurements of nasal NO concentrations are helpful to screen children with clinical symptoms suggestive of primary ciliary dyskinesia and to exclude this disease in those with high nasal NO concentrations with high certainty. Nasal NO measurements are, however, of no diagnostic utility in distinguishing between other conditions such as asthma, cystic fibrosis, bronchiectasis, sinusitis or rhinitis, or in monitoring therapeutic interventions in any such disorder.
\end{abstract}

\section{Origin of Nasal Nitric Oxide}

Nitric oxide (NO) is produced endogenously within the respiratory tract and was first documented in exhaled air in humans and mammals in 1991 [1]. It was then shown that the major part of NO in exhaled air originates from the nasal airways, with only a minor contribution from the lower airways and the oral cavity [2]. NO is present in the nasal airways and paranasal sinuses in very high concentrations, close to the acute exposure levels set by occupational health guidelines for short-term exposure at the workplace $[3,4]$.

\section{Biochemical Pathway and Cellular Origin}

NO is generated from the semi-essential amino acid $L$-arginine by the enzyme NO synthase (NOS), which can be divided into two major categories: constitutive NOS (cNOS) and inducible NOS (iNOS). The constitutive enzyme, which according to its location may be named endothelial NOS (eNOS) or neuronal NOS (nNOS), is activated by calcium and calmodulin. It produces small amounts of NO to modulate physiological processes, and can be stimulated by bradykinin, acetylcholine, histamine, leukotrienes, and several other mediators. Calmodulin is an enzyme cofactor regulating electron transport. It is also identified in close juxtaposition to the cilia of the upper airway epithelium, and is thought to be involved in ciliary motility. The iNOS, which was first isolated in macrophages, is calciumand calmodulin-independent and activated by a variety of 
pro-inflammatory cytokines and endotoxins. The induction of iNOS requires gene transcription. Hence, an increase in NO production takes hours, but it may continue for days. When activated, iNOS produces up to 1,000 times more NO than cNOS. Corticosteroids only inhibit iNOS [5]. The different NOS are coded by genes on chromosomes 7 (eNOS), 12 (nNOS), and 17 (iNOS). NOS requires oxygen and nicotinamide adenine dinucleotide phosphate as cosubstrates to oxidize $L$-arginine to $L$-citrulline and NO.

Many cells in the upper and lower respiratory system produce cNOS including parasympathetic vasodilator nerves, endothelial cells, and ciliated mucosa cells. iNOS has been reported to be present not only in epithelium but also in macrophages, fibroblasts, neutrophils, endothelium and vascular smooth muscle. The NOS found in abundance in the apical regions of the maxillary sinus epithelium most closely resembles the inducible isoform. It is, however, constantly expressed and not inhibited by steroids which are characteristics commonly associated with cNOS rather than iNOS [3]. It is localized mainly within cilia and microvilli and held responsible for the high NO concentrations within the sinus lumen of healthy humans $[3,6]$.

\section{Anatomic Origin}

The epithelial cells of the paranasal sinuses were identified as a major source of NO production in the respiratory tract. NO concentrations inside the paranasal sinus are several hundred times higher than in exhaled air from lower airways [3,000-25,000 parts per billion (ppb)]. The sinuses communicate with the nasal cavity through their ostia and the rate of gas exchange between these cavities is dependent on several factors such as the size of the ostia, the volume of the sinuses, the nasal airflow, and intranasal pressure. There is still some controversy whether the majority of NO measured in nasal air originates from the paranasal sinuses or from the mucosa of the nasal cavity. The low concentrations of NO found intranasally during an acute sinusitis as well as its increase after antibiotic therapy have preferentially been explained by obstruction and opening of the sinus ostia, respectively [7]. Recent data, however, suggest that iNOS expression is markedly reduced in the sinus epithelium of patients with maxillary sinusitis [6]. Hence, patency of sinus ostia is not the only factor affecting nasal NO concentration during sinusitis. High concentrations of NO are found in the nose of neonates shortly after birth, even before the sinuses have developed [8]. In a unique study, the osteomeatal complex and sphenoethmoidal recess were occluded in one volunteer to isolate the nose from the sinuses. It was shown that, when all the sinus ostia are blocked, nasal NO output is decreased by only $12 \%$. Interestingly, after ostial occlusion paranasal sinus NO concentration reached a plateau at about $30,000 \mathrm{ppb}$. This suggests a negative feedback mechanism limiting NO output above a certain local concentration. Further measurements also suggested that, although the NO output per square unit of mucosa was smaller in the nose than in the sinuses, the majority of nasal NO is still derived from the nose itself, because of its larger surface area [9].

\section{Physiological Role of Nasal NO}

NO production is commonly enhanced at sites of inflammation. The physiological role of the very high local NO concentration in the paranasal sinuses is still unclear. NO is bacteriostatic at such high concentrations and may contribute to the local host defence of these cavities [3]. It may also play an important role in the regulation of ciliary function $[10,11]$. Pulmonary vascular resistance is decreased in humans during nasal breathing compared to that during mouth breathing, intubation or after tracheotomy $[12,13]$. This implies that nasally derived NO acts by autoinhalation as an aerocrine messenger to modulate the pulmonary vascular tone and to improve ventilation/perfusion matching.

\section{Methodology of Measuring Nasal NO [14]}

Many brilliant experimental techniques have been used to measure NO production at the various sites of the upper airways to arrive at the current understanding of nasal NO physiology. The measured NO concentrations differed widely, because they depend highly on the technology and measurement techniques used. Therefore, international task forces have tried to set standards for NO measurements to enable the comparison of results from different laboratories. This chapter will review the currently recommended technique to measure nasal NO concentrations for diagnostic purposes in clinical practice $[15,16]$.

\section{Terminology and Units}

The nasal airway is a complex system of communicating cavities composed of the nasal cavities, paranasal sinuses, the middle ear, and the nasopharynx. Measurements of nasal NO provide no information with respect to the anatomical source of the gas or the physiological processes that generate the NO. The fractional concentration of nasal NO is termed nasal $\mathrm{FE}_{\mathrm{NO}}$ and expressed in ppb, which is equivalent to nanolitres per litre. Nasal NO output represents the amount of nasal NO exhaled per time unit, and is denoted nasal $\dot{\mathrm{V}}_{\mathrm{NO}}$. It is calculated from the product of $\mathrm{NO}$ 

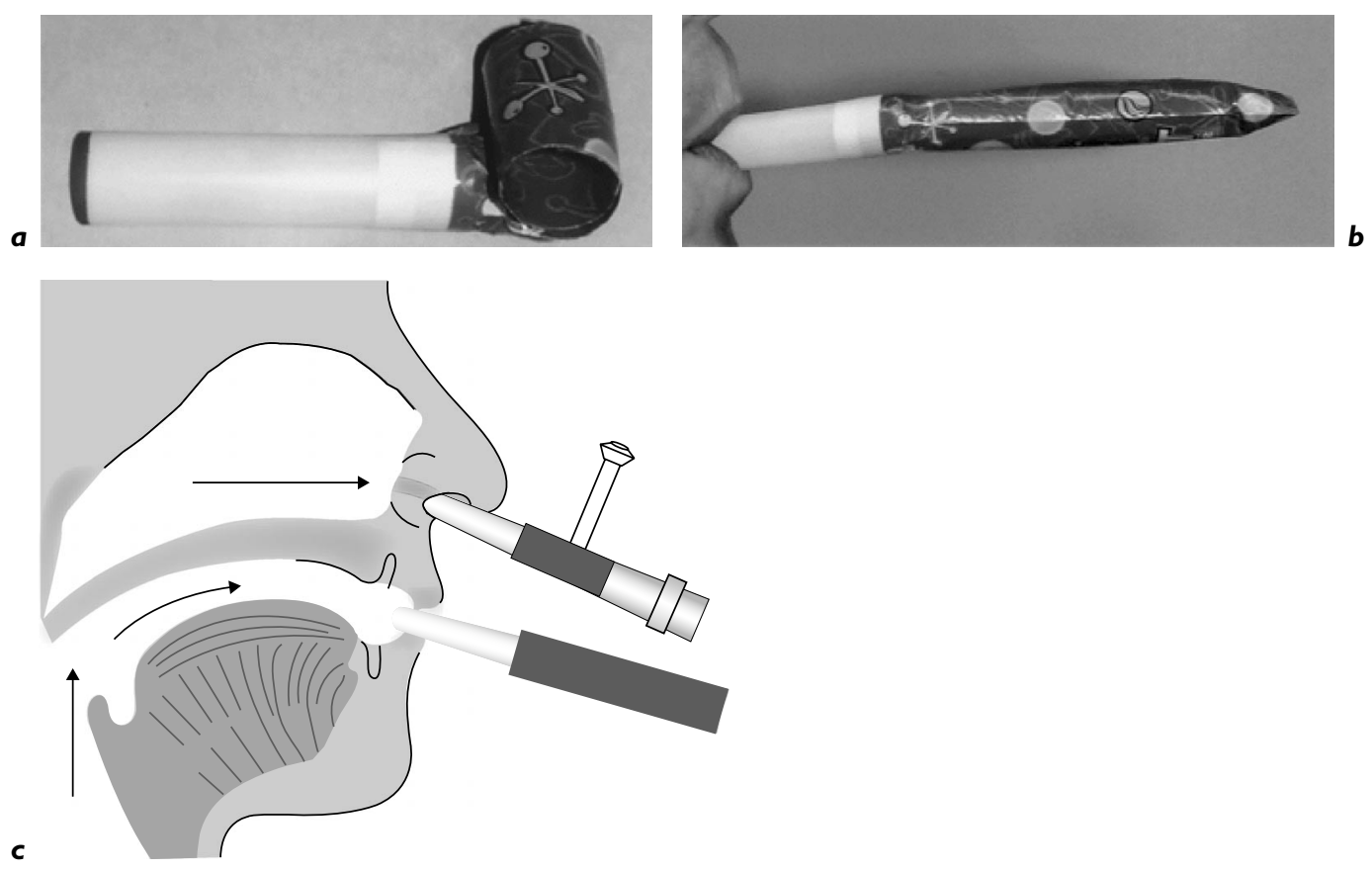

Fig. 1. $\boldsymbol{a}$ Party toy. $\boldsymbol{b}$ Party toy inflated. $\boldsymbol{c}$ Velopharyngeal closure achieved with inflation of party toy [reproduced with permission from 21].

concentration in nanolitres per litre and expiratory flow rate in litres per minute, corrected to BTPS.

\section{NO Analyzer}

NO is measured in exhaled air by chemiluminescence which is based on the emission of light from the reaction of $\mathrm{NO}$ with ozone $\left(\mathrm{O}_{3}\right)$ to $\mathrm{NO}_{2}$. The quantity of light emitted is proportional to the concentration of NO [17]. The extremely high sensitivity and fast response time of modern NO analyzers permit continuous on-line measurements of $\mathrm{NO}$ in exhaled air. Minimum standards for suitable chemiluminescence NO analyzers have been described in detail with respect to linearity and accuracy ( $\pm 1 \%$ full range), lower detectable limit ( $\leq 1 \mathrm{ppb}$ ), response time (fast lag time and rise time), and measurement range $(0.1-10,000 \mathrm{ppb})$ [15].

\section{Description of Standard Technique}

Measurement of nasal NO output requires generation of air flow through the nasal cavity (transnasal air flow). While the velum is closed, transnasal flow can be achieved by various aspiration or insufflation methods which generate flow through the nasal cavities in series (air circulates from one naris to the other) or in parallel. Aspiration at a fixed flow through the nasal passages in series is currently the most widely used and best-validated method to sample nasal NO in isolation from the lower respiratory tract.

\section{Velum Closure}

Measurements have to be performed during velum closure to exclude air entry from the lower respiratory tract and to prevent a loss of nasal air via the posterior velopharyngeal aperture. Recommended methods to achieve velum closure are: (1) inhalation to total lung capacity and exhalation against an expiratory resistance while targeting a mouth pressure of $10 \mathrm{~cm} \mathrm{H}_{2} \mathrm{O}$ [18], (2) breath holding [19], (3) pursed lip breathing [20], and (4) sustained inflation of a party toy [21].

Slow oral exhalation against a resistance of at least $10 \mathrm{~cm}$ $\mathrm{H}_{2} \mathrm{O}$ has been chosen as the preferred method in adults, but any method that can reliably close the velum is acceptable. It is our experience and the experience of others that in older children velum closure can be reliably achieved by breath holding or exhalation into a balloon or 'party toys' which can act as expiratory resistors (fig. 1) [21, 22]. The children are asked to keep the party toy inflated until a maximum plateau NO concentration is reached. The sustained inflation of the party toy indicates that palatal closure is reliably achieved. Simultaneous measurement of nasal $\mathrm{CO}_{2}$ is used 


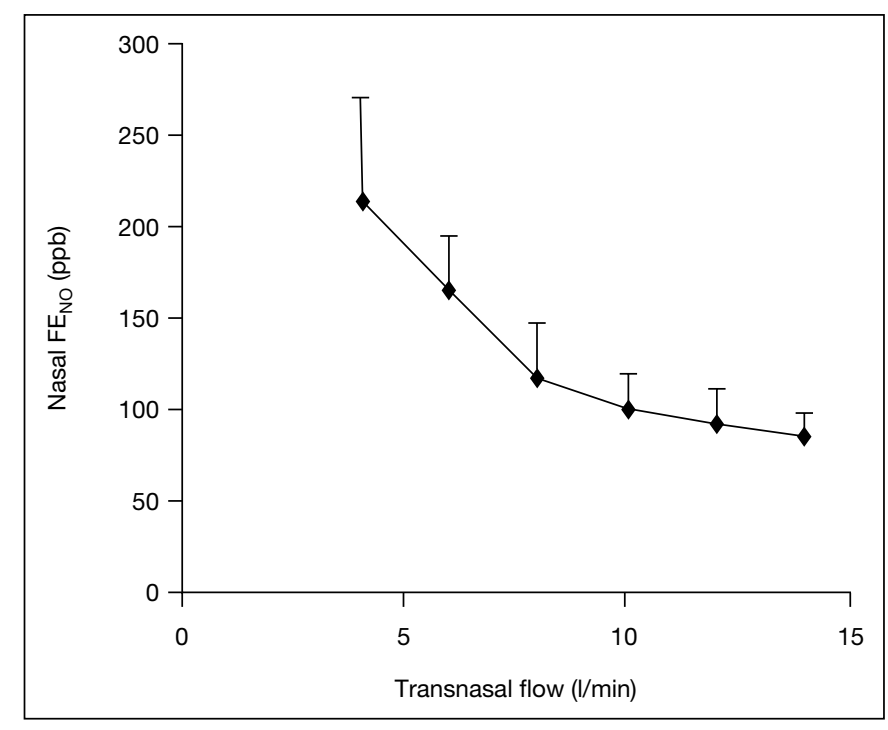

Fig. 2. Inverse correlation of nasal $\mathrm{NO}$ concentration $\left(\mathrm{FE}_{\mathrm{NO}}\right)$ with transnasal flow rate [reproduced with permission from 16].

to verify velum closure and to demonstrate the absence of contamination with exhaled air from the lower airways. There is, however, no validated technique to measure nasal NO concentrations in infants and young children who are unable to perform velum closure manoeuvres.

\section{Aspiration or Sampling Flow}

It is essential to measure the NO concentration at a known and fixed aspiration flow, because nasal NO concentration is inversely related to transnasal flow rate (fig. 2) [23]. The transnasal or aspiration flow should be measured and recorded against time together with the NO concentration and $\mathrm{CO}_{2}$ level. The constant transnasal flow produces a washout phase of $\mathrm{NO}$ followed by the establishment of a steady plateau documented in the profile of NO (fig. 3). It has been demonstrated that nasal NO output varies with the magnitude of aspiration flow, despite the achievement of a steady-state plateau of NO concentration in the aspired air. NO output is higher when measured at transnasal flows in the magnitude of $2.7-3.71 / \mathrm{min}$ compared with lower flows of $0.2-0.71 / \mathrm{min}$. The higher flows produce a turbulent instead of a laminar flow pattern and facilitate ventilation of the narrow peripheral parts of the nasal airway. It is also argued that the efficacy of NO removal from the nasal mucosa is higher with turbulent flow, as is water and heat transfer. These turbulent flows also most closely resemble physiological flows during quiet nasal breathing.

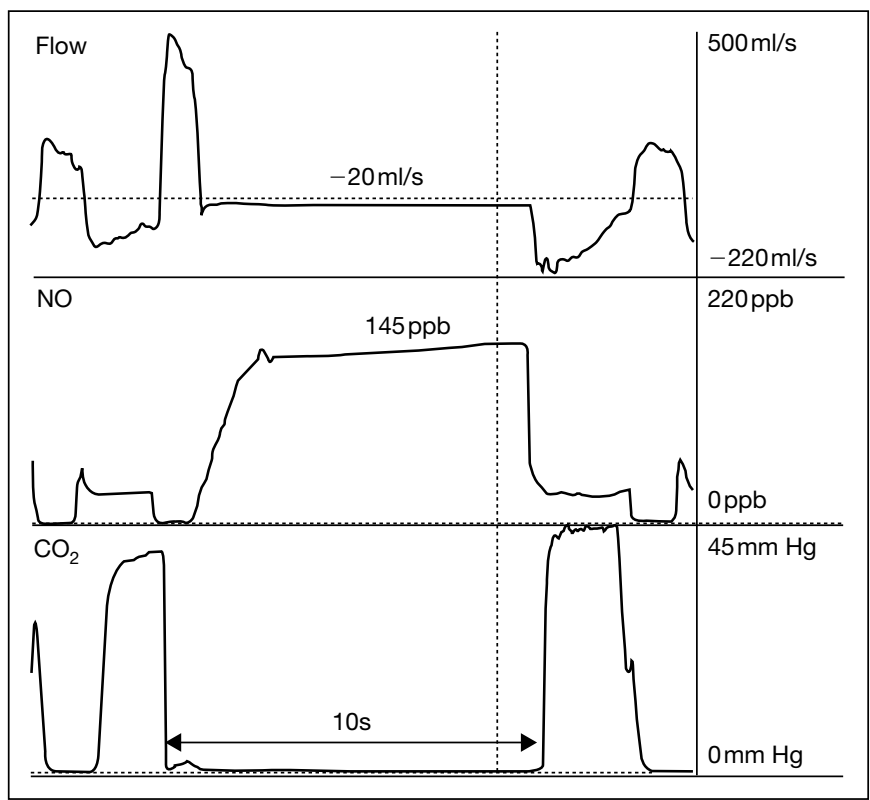

Fig. 3. Simultaneous measurements of flow, NO concentration and $\mathrm{CO}_{2}$ level against time. The NO trace shows a washout phase and steady plateau at a fixed transnasal flow of $20 \mathrm{ml} / \mathrm{s}$. The $\mathrm{CO}_{2}$ signal confirms the absence of contamination with alveolar air.

Hence, NO measurements obtained at low laminar flows may underestimate NO output compared to measurements at higher and more physiological transnasal flow rates. By reporting the NO output instead of the NO concentration, measurements at different flows become comparable, provided the aspiration flow is within the flow range that provides maximal and stable $\mathrm{NO}$ concentrations (0.9$6.01 / \mathrm{min}$ ) [24]. An ATS task force defined $3.01 / \mathrm{min}$ as the optimal flow to measure nasal $\mathrm{NO}$ concentration in adults [16]. However, no specific recommendations were made for optimal transnasal flows in children, which are likely to be lower. The optimal range of flows was later reported to be $3.2-5.21 / \mathrm{min}$ in adults and $2.2-$ $3.21 / \mathrm{min}$ in children [25]. We obtained steady plateau NO concentrations in children with transnasal flows at $1.2 \mathrm{l} / \mathrm{min}$ [22]. It is recommended to increase aspiration flow rates up to $61 / \mathrm{min}$, if a steady NO plateau is not achieved. The precise flow used should be documented for each subject.

\section{Technique}

Nasal NO is measured in the child sitting with an olive introduced approximately $1 \mathrm{~cm}$ inside one nostril ensuring a tight seal while the contralateral nostril is left open 

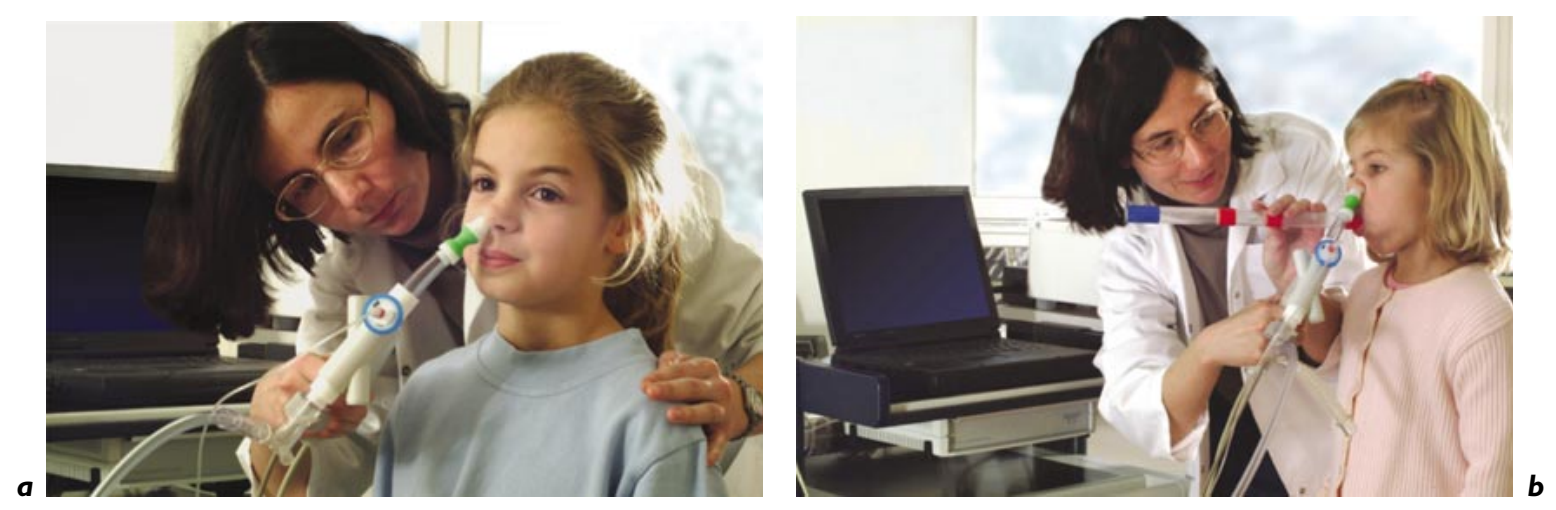

Fig. 4. Measurements of nasal NO output during breath hold (a) and during constant insufflation into an expiratory resistor (b). Aspiration flow is measured by an ultrasonic spirometer connected to a vacuum source and $\mathrm{CO}_{2}$ by capnography, respectively.

(eventually with the help of another nozzle). This olive should be composed of a soft, non-traumatizing material, and be of sufficient diameter and appropriate shape to occlude the naris. Air is aspirated at a constant flow rate by a suction pump while the velum is closed by an appropriate technique for at least $10 \mathrm{~s}$. A side port just distal to the olive samples gas for NO analysis (fig. 4). A tight-fitting mask covering the nose may also be used for nasal NO measurements.

\section{Humming and Assessment of Sinus Ventilation}

Nasal NO concentrations increase largely (15-fold) during humming compared to silent exhalation [26]. This is explained by an increased washout of air, and hence NO, from the paranasal sinuses into the nasal cavity by the oscillating sound waves. The increase in nasal NO during humming is absent if the sinus ostia are completely obstructed. Hence, combined nasal NO measurements with and without humming could be of use to estimate sinus ventilation and to assess the relative contribution of the nasal cavity and the sinuses to nasal NO output [27]. Nasal NO is markedly decreased following repeated consecutive humming manoeuvres and recovers to baseline concentrations after a 3-min period of silence. This pattern fits well with the notion that humming empties the sinuses and that a period of silence will allow for NO to accumulate again. It is of interest that posthumming nasal NO measurements are characterized by less intrasubject variability in comparison with measurements performed after a short period of speaking or silence [28]. Posthumming measurements may serve as a measure of NO output from the nasal cavity mucosa.

\section{Factors Influencing Nasal NO Values}

There is only limited knowledge on whether and how physiological, pharmacological, and external factors affect nasal NO output. It is evident that breath holding or nose occlusion increase nasal NO measurements.

\section{Ambient Air}

Ambient NO concentrations are highly variable and can reach concentrations that may cause considerable errors if ambient air is used as the gas source for transnasal flow. This is of utmost concern if ambient NO concentrations are higher than nasal NO concentrations, e.g. in conditions with very low nasal NO output such as primary ciliary dyskinesia (PCD). The use of NO-free air as gas source for transnasal flow is recommended to eliminate this problem. In any case, the ambient NO concentration should be recorded and taken into consideration for correct interpretation of nasal NO measurements.

\section{Smoking}

The effect of prenatal or postnatal tobacco smoke exposure on nasal NO concentration has not been investigated in children. Nasal NO concentrations are slightly lower in smokers [29].

\section{Age}

It has been hypothesized that nasal NO concentrations rise from birth until the age of 10 years with pneumatization of the sinuses, although when related to body weight NO output in preterm infants was shown to be similar to 
Table 1. Published studies measuring nasal NO in healthy children

\begin{tabular}{|c|c|c|c|c|c|c|}
\hline Study & $\mathrm{n}$ & $\begin{array}{l}\text { Age } \\
\text { years }\end{array}$ & Technique & $\begin{array}{l}\text { Aspiration } \\
\text { flow, } 1 / \mathrm{min}\end{array}$ & $\begin{array}{l}\text { No output, } \\
\mathrm{nl} / \mathrm{min}\end{array}$ & $\begin{array}{l}\text { NO concentration, } \\
\mathrm{ppb}\end{array}$ \\
\hline Corbelli et al. [22] & 24 & $12.4(4.5-24)$ & Breath hold & 1.2 & & $223.7(90-950)$ \\
\hline Daya et al. [21] & 30 & $10.7(3.3-17.5)$ & Breath hold & 3 & $\begin{array}{l}458 \\
(131-1,424)\end{array}$ & \\
\hline Narang.et al. [48] & 53 & $10.7(5.5-19)$ & Breath hold & 0.25 & & $716(398-1,437)$ \\
\hline Karadag et al. [36] & 20 & $\sim 10.8$ & Breath hold & 0.25 & & $553(116-1,437)$ \\
\hline Baraldi et al. [38] & 133 & $6-15$ & Tidal breathing & 0.7 & & $\begin{array}{l}216(95 \% \\
\text { CI } 204-228)\end{array}$ \\
\hline $\begin{array}{l}\text { Balfour-Lynn } \\
\text { et al. [37] }\end{array}$ & 54 & $12.2(6-17)$ & Breath hold & 0.25 & & $1,024(158-2,502)$ \\
\hline Lundberg et al. [40] & 19 & $5-15$ & Tidal breathing & 0.7 & & $239(\mathrm{SD} 20)$ \\
\hline Dötsch et al. [46] & 37 & $4-18$ & Tidal breathing & 0.7 & & 101 (SD 49) \\
\hline
\end{tabular}

Data represent mean or median with the range in parentheses except where stated otherwise. $\mathrm{CI}=$ Confidence interval; $\mathrm{SD}=$ standard deviation.

adults [30]. More work is needed to clarify age-related changes in nasal NO output from infancy to adulthood using comparable methods. Nasal NO concentrations in adults are not affected by aging.

\section{Physical Exercise}

Nasal NO concentrations decrease by about $50 \%$ during physical exercise and reach normal baseline concentrations in about $15-20 \mathrm{~min}[31,32]$. The reason for the decrease in nasal NO output during exercise has not yet been elucidated.

\section{Drugs}

Data on the effect of pharmacological substances on nasal NO output is limited. Nasal decongestants, such as oxymetazoline and xylometazoline, decrease nasal NO concentrations by about $15 \%$ and have a dose-dependent inhibitory effect on total iNOS activity in vitro [33, 34]. Histamine, topical and systemic steroids, and antibiotics have no effect on nasal NO concentrations in healthy persons [35].

\section{Normal Data of Nasal NO Measurements in Children}

Data obtained from healthy children demonstrate considerable intersubject variation resulting in a broad range of normal nasal NO output [21]. Normal values have yet to be established in a larger population of healthy children of different ages using the recommended aspiration technique
Table 2. Effect of diseases on nasal NO concentrations in children

\begin{tabular}{ll}
\hline Disease & Nasal NO concentration \\
\hline $\begin{array}{l}\text { Common cold, upper } \\
\text { respiratory tract infection }\end{array}$ & Unchanged \\
Allergic rhinitis & $\begin{array}{c}\text { Increased } \\
\text { (decreased with topical steroids) }\end{array}$ \\
Asthma & Unchanged \\
Acute sinusitis & Decreased \\
Cystic fibrosis & Decreased \\
Non-cystic fibrosis or & Decreased \\
non-PCD bronchiectasis & \\
PCD & Extremely low \\
\hline
\end{tabular}

during breath holding. Previous studies reporting nasal NO concentrations in healthy children are summarized in table 1 . Intrasubject coefficients of variation of repeated measurements by the aspiration technique are between 4 and $8 \%$ in healthy children [36-38].

\section{Diagnostic Use in Paediatric Respiratory Diseases}

Nasal NO concentrations are increased in asthma, allergic rhinitis, and viral respiratory infections, but are reduced in sinusitis, cystic fibrosis, PCD, bronchiectasis, chronic cough, diffuse panbronchiolitis, and after exposure to tobacco and alcohol (table 2) [37, 39-46]. The most 
Table 3. Published studies reporting sensitivity and specificity of nasal NO concentrations in discriminating between patients with PCD and non-PCD bronchiectasis

\begin{tabular}{lllllll}
\hline Study & $\begin{array}{l}\text { Aspiration } \\
\text { flow, 1/min }\end{array}$ & $\begin{array}{l}\text { Cutoff } \\
\text { level, ppb }\end{array}$ & Sensitivity, \% & Specificity, \% & $\begin{array}{l}\text { Positive } \\
\text { predictive } \\
\text { value, } \%\end{array}$ & $\begin{array}{l}\text { Negative } \\
\text { predictive } \\
\text { value, } \%\end{array}$ \\
\hline Horvath et al. [51] & 0.25 & 187 & 93 & 95 & 87 & 97 \\
Narang et al. [48] & 0.25 & 250 & 97 & 90 & 83 & 97 \\
Corbelli et al. [22] & 1.2 & 105 & 94 & 88 & 89 & 94 \\
\hline
\end{tabular}

comprehensive and significant changes in nasal NO concentrations in relation to normal values can be documented in patients with PCD. Current knowledge suggests that the measurement of nasal NO concentrations may be of clinical value in clarifying diagnostic problems in patients with clinical suspicion of PCD. Nasal NO measurements are, however, of no diagnostic utility in distinguishing between conditions such as asthma, cystic fibrosis, bronchiectasis, sinusitis or rhinitis, or in monitoring therapeutic interventions in any such disorder.

\section{Primary Ciliary Dyskinesia}

PCD constitutes a recessively inherited group of disorders of ciliary structure and/or function resulting in impaired mucociliary clearance. Typical structural ciliary abnormalities include absent inner or outer dynein arms, and radial spoke and tubular defects. The clinical manifestations are recurrent or chronic respiratory tract infections with mucus retention as there are rhinitis, sinusitis, serous otitis media, and bronchitis. Mirror image arrangement occurs in $50 \%$ of the patients (Kartagener syndrome) [47].

Measurements of nasal NO concentrations in patients with PCD are extremely low compared to healthy children or children with other respiratory disorders $[22,36$, 48-52]. There is no relationship between the different structural defects in PCD and the levels of nasal NO concentration [52]. The reason for the low nasal NO concentrations in patients with PCD has not yet been clarified. Several observations suggest that NO plays an important role in signal transduction associated with ciliary motility. The epithelial NOS is localized at the basal body of the microtubules of the cilia, and NO has been found to stimulate ciliary beat frequency $[6,53]$. It seems, however, unlikely that the lower levels of nasal and also exhaled NO concentrations in PCD are the results of reduced NOS activity, because levels of NO metabolites are not different between patients with PCD and healthy subjects [54].

Measurements of nasal NO concentrations are helpful to screen children with clinical symptoms suggestive of PCD and to decide on the need for further, more invasive testing. This is strengthened by the high sensitivity and specificity of nasal NO concentrations to discriminate between PCD and other disorders with chronic airway inflammation, such as cystic fibrosis and non-PCD bronchiectasis (table 3 ). If nasal NO concentration is unexpectedly low in a patient with recurrent respiratory infections, the diagnosis of PCD should be actively excluded. This is done by assessing the ciliary beat frequency by light microscopy, and searching for the typical ultrastructural defects of the cilia by electron microscopy in mucosal biopsy specimens. 


\section{References}

1 Gustafsson LE, Leone AM, Persson MG, Wiklund NP, Moncada S: Endogenous nitric oxide is present in the exhaled air of rabbits, guinea pigs and humans. Biochem Biophys Res Commun 1991;181:852-857.

2 Alving K, Weitzberg E, Lundberg JM: Increased amount of nitric oxide in exhaled air of asthmatics. Eur Respir J 1993;6: 1368-1370.

3 Lundberg JO, Farkas-Szallasi T, Weitzberg E, Rinder J, Lidholm J, Anggaard A, Hokfelt T, Lundberg JM, Alving K: High nitric oxide in human paranasal sinuses. Nat Med 1995;1: 370-373.

4 Occupational Health Guideline for Nitric Oxide. National Institute for Occupational Safety and Health. Occupational Health Guidelines for Chemical Hazards. DHHS (NIOSH) Publication 1981; http://www.cdc. gov/niosh/pdfs/0448.pdf

5 Asano K, Chee CB, Gaston B, Lilly CM, Gerard C, Drazen JM, Stamler JS: Constitutive and inducible nitric oxide synthase gene expression, regulation and activity in human lung epithelial cells. Proc Natl Acad Sci USA 1994;91:10089-10093.

6 Deja M, Busch T, Bachmann S, Riskowski K, Campean V, Wiedmann B, Schwabe M, Hell B, Pfeilschifter J, Falke KJ, Lewandowski K: Reduced nitric oxide in sinus epithelium of patients with radiologic maxillary sinusitis and sepsis. Am J Respir Crit Care Med 2003; 168:281-286.

7 Baraldi E, Azzolin NM, Biban P, Zacchello F: Effect of antibiotic therapy on nasal nitric oxide concentration in children with acute sinusitis. Am J Respir Crit Care Med 1997; 155:1680-1683.

8 Williams O, Rafferty GF, Hannam S, Milner AD, Greenough A: Nasal and lower airway levels of nitric oxide in prematurely born infants. Early Hum Dev 2003;72:67-73.

9 Haight JS, Djupesland PG, Qjan W, Chatkin JM, Furlott H, Irish J, Witterick I, McClean P, Fenton RS, Hoffstein V, Zamel N: Does nasal nitric oxide come from the sinuses? J Otolaryngol 1999;28:197-204.

10 Kim JW, Min YG, Rhee CS, Lee CH, Koh YY, Rhyoo C, Kwon TY, Park SW: Regulation of mucociliary motility by nitric oxide and expression of nitric oxide synthase in the human sinus epithelial cells. Laryngoscope 2001;111:246-250

11 Lindberg S, Cervin A, Runer T: Low levels of nasal nitric oxide (NO) correlate to impaired mucociliary function in the upper airways. Acta Otolaryngol 1997;117:728-734.

12 Settergren G, Angdin M, Astudillo R, Gelinder $\mathrm{S}$, Liska J, Lundberg JO, Weitzberg E: Decreased pulmonary vascular resistance during nasal breathing: Modulation by endogenous nitric oxide from the paranasal sinuses. Acta Physiol Scand 1998;163:235-239.

13 Lundberg JO, Settergren G, Gelinder S, Lundberg JM, Alving $\mathrm{K}$, Weitzberg $\mathrm{E}$ : Inhalation of nasally derived nitric oxide modulates pulmonary function in humans. Acta Physiol Scand 1996;158:343-347.
14 Kissoon N, Duckworth L, Blake K, Murphy S, Silkoff PE: Exhaled nitric oxide measurements in childhood asthma: Techniques and interpretation. Pediatr Pulmonol 1999;28: 282-296.

15 Kharitonov S, Alving K, Barnes PJ: Exhaled and nasal nitric oxide measurements: Recommendations. The European Respiratory Society Task Force. Eur Respir J 1997;10: 1683-1693

16 American Thoracic Society: Recommendations for standardized procedures for the online and offline measurement of exhaled lower respiratory nitric oxide and nasal nitric oxide in adults and children. Am J Respir Crit Care Med 1999; 160:2104-2117.

17 Archer S: Measurement of nitric oxide in biological models. FASEB J 1993;7:349-360.

18 Silkoff PE, McClean PA, Slutsky AS, Furlott HG, Hoffstein E, Wakita S, Chapman KR, Szalai JP, Zamel N: Marked flow-dependence of exhaled nitric oxide using a new technique to exclude nasal nitric oxide. Am J Respir Crit Care Med 1997;155:260-267.

19 Kimberly B, Nejadnik B, Giraud GD, Holden WE: Nasal contribution to exhaled nitric oxide at rest and during breathholding in humans. Am J Respir Crit Care Med 1996; 153:829-836.

20 Rodenstein DO, Stanescu DC: Absence of nasal air flow during pursed lips breathing. The soft palate mechanisms. Am Rev Respir Dis 1983;128:716-718.

21 Daya H, Qian W, McClean P, Haight J, Zamel $\mathrm{N}$, Papsin BC, Forte V: Nasal nitric oxide in children: A novel measurement technique and normal values. Laryngoscope 2002;112: 1831-1835.

22 Corbelli R, Bringolf-Isler B, Amacher A, Sasse B, Spycher M, Hammer J: Nasal nitric oxide measurements to screen children for primary ciliary dyskinesia? Chest 2004;126: 1054-1059.

23 Silkoff PE, Chatkin J, Qian W, Chakravorty S, Gutierrez C, Furlott H, McClean P, Rai S, Zamel N, Haight J: Nasal nitric oxide: A comparison of measurement techniques. Am J Rhinol 1999;13:169-178.

24 Imada M, Iwamoto J, Nonaka S, Kobayashi Y, Unno T: Measurement of nitric oxide in human nasal airway. Eur Respir J 1996;9:556-559.

25 Qian W, Djupesland PG, Chatkin JM, McClean P, Furlott H, Chapnik JS, Zamel N, Haight JS Aspiration flow optimized for nasal nitric oxide measurement. Rhinology 1999; 37:61-65.

26 Weitzberg E, Lundberg JO: Humming greatly increases nasal nitric oxide. Am J Respir Crit Care Med 2002;166:144-145.

27 Maniscalco M, Weitzberg E, Sundberg J, Sofia M, Lundberg JO: Assessment of nasal and sinus nitric oxide output using singlebreath humming exhalations. Eur Respir J 2003;22:323-329.

28 Maniscalco M, Sofia M, Weitzberg E, Carratu L, Lundberg JO: Nasal nitric oxide measurements before and after repeated humming maneuvers. Eur J Clin Invest 2003 ; 33:1090-1094.
29 Olin AC, Hellgren J, Karlsson G, Ljungkvist G, Nolkrantz K, Toren K: Nasal nitric oxide and its relationship to nasal symptoms, smoking and nasal nitrate. Rhinology 1998;36:117-121.

30 Artlich A, Bush T, Lewandowsky K: Exhaled nitric oxide in preterm infants. Respir Physiol 1998;114:195-200.

31 Phillips CR, Giraud GD, Holden WE: Exhaled nitric oxide during exercise: Site of release and modulation by ventilation and blood flow. J Appl Physiol 1996;80:1865-1871.

32 Lundberg JON, Rinder J, Weitzberg E, Alving K: Heavy physical exercise decreases nitric oxide levels in the nasal airways in humans. Acta Physiol Scand 1997;159:51-57.

33 Ferguson EA, Eccles R: Changes in nasal nitric oxide concentration associated with symptoms of common cold and treatment with a topical nasal decongestant. Acta Otolaryngol 1997;117:614-617.

34 Westerveld GJ, Voss HP, van der Hee RM, de Haan-Koelewijn GJ, den Hartog GJ, Scheeren RA, Bast A: Inhibition of nitric oxide synthase by nasal decongestants. Eur Respir J 2000; 16:437-444.

35 Lundberg JON, Weitzberg E, Lundberg JM, Alving K: Nitric oxide in exhaled air. Eur Respir J 1996;9:2671-2680.

36 Karadag B, James AJ, Gultekin E, Wilson NM, Bush A: Nasal and lower airway level of nitric oxide in children with primary ciliary dyskinesia. Eur Respir J 1999;13:1402-1405.

37 Balfour-Lynn IM, Laverty A, Dinwiddie R: Reduced upper airway nitric oxide in cystic fibrosis. Arch Dis Child 1996;75:319-322

38 Baraldi E, Azzolin NM, Cracco A, Zacchello F: Reference values of exhaled nitric oxide for healthy children 6-15 years old. Pediatr Pulmonol 1999;27:54-58.

39 Baraldi E, Azzolin NM, Carra S, Dario C, Marchesini L, Zacchello F: Effect of topical steroids on nasal nitric oxide production in children with perennial allergic rhinitis: A pilot study. Respir Med 1998;92:558-561.

40 Lundberg JON, Nordvall SL, Weitzberg E, Kollberg H, Alving K: Exhaled nitric oxide in paediatric asthma and cystic fibrosis. Arch Dis Child 1996;75:323-326.

41 Arnal JF, Didier A, Rami J, M'Rini C, Charlet JP, Serrano E, Besombes JP: Nasal nitric oxide is increased in allergic rhinitis. Clin Exp Allergy 1997;27:358-362.

42 Kharitonov SA, Rajakulasingam K, O'Connor B, Durham SR, Barnes PJ: Nasal nitric oxide is increased in patients with asthma and allergic rhinitis and may be modulated by nasal glucocorticoids. J Allergy Clin Immunol 1997;99:58-64

43 Thomas SR, Kharitonov SA, Scott SF, Hodson ME, Barnes PJ: Nasal and exhaled nitric oxide is reduced in adult patients with cystic fibrosis and does not correlate with cystic fibrosis genotype. Chest 2000;117:1085-1089.

44 Nakano H, Ide H, Imada M, Osanai S, Takahashi T, Kikuchi K, Iwamoto J: Reduced nasal nitric oxide in diffuse panbronchiolitis. Am J Respir Crit Care Med 2000;162: 2218-2220 
45 Lindberg S, Cervin A, Runer T: Low levels of nasal nitric oxide (NO) correlate to impaired mucociliary function in the upper airways. Acta Otolaryngol 1997;117:728-734.

46 Dötsch J, Demirakca S, Terbrack HG, Huls G, Rascher W, Kuhl PG: Airway nitric oxide in asthmatic children and patients with cystic fibrosis. Eur Respir J 1996;9:2537-2540.

47 Bush A, Cole P, Hariri M, Mackay I, Phillips G, O'Callaghan C, Wilson R, Warner JO: Primary ciliary dyskinesia: Diagnosis and standards of care. Eur Respir J 1998;12:982-988.

48 Narang I, Ersu R, Wilson NM, Bush A: Nitric oxide in chronic airway inflammation in children: Diagnostic use and pathophysiological significance. Thorax 2002;57:586-589.

49 Lundberg JO, Weitzberg E, Nordvall SL, Kuylenstierna R, Lundberg JM, Alving K: Primarily nasal origin of exhaled nitric oxide and absence in Kartagener's syndrome. Eur Respir J 1994;7:1501-1504.
50 Wodehouse T, Kharitonov SA, Mackay IS, Barnes PJ, Wilson R, Cole PJ: Nasal nitric oxide measurements for the screening of primary ciliary dyskinesia. Eur Respir J 2003; 21:43-47.

51 Horvath I, Loukides S, Wodehouse T, Csiszer E, Cole PJ, Kharitonov SA, Barnes PJ: Comparison of exhaled and nasal nitric oxide and exhaled carbon monoxide levels in bronchiectatic patients with and without primary ciliary dyskinesia. Thorax 2003;58:68-72.

52 Noone PG, Leigh MW, Sannuti A, Minnix SL, Carson JL, Hazucha M, Zariwala MA, Knowles MR: Primary ciliary dyskinesia. Diagnostic and phenotypic features. Am J Respir Crit Care Med 2004;169:459-467.

53 Doran SA, Tran CH, Eskicioglu C, Stachniak T, Ahn KC, Goldberg JI: Constitutive and permissive roles of nitric oxide activity in embryonic ciliary cells. Am J Physiol Regul Integr Comp Physiol 2003;285:R348-R355.
54 Csoma Z, Bush A, Wilson NM, Donnelly L, Balint B, Barnes PJ, Kharitonov SA: Nitric oxide metabolites are not reduced in exhaled breath condensate of patients with primary ciliary dyskinesia. Chest 2003;124:633-638.

Prof. Dr. med. Jürg Hammer

Head, Division of Intensive Care and Pulmonology

University Children's Hospital Base

Römergasse 8, CH-4005 Basel (Switzerland)

Tel. +41616856565

Fax +41616855059

E-Mail juerg.hammer@unibas.ch 